\title{
Electric field stimulation for tissue engineering applications
}

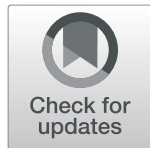

\author{
Christina N. M. Ryan ${ }^{1,2+}$, Meletios N. Doulgkeroglou ${ }^{1,2+}$ and Dimitrios I. Zeugolis ${ }^{1,2,3^{*}}$ (D)
}

\begin{abstract}
Electric fields are involved in numerous physiological processes, including directional embryonic development and wound healing following injury. To study these processes in vitro and/or to harness electric field stimulation as a biophysical environmental cue for organised tissue engineering strategies various electric field stimulation systems have been developed. These systems are overall similar in design and have been shown to influence morphology, orientation, migration and phenotype of several different cell types. This review discusses different electric field stimulation setups and their effect on cell response.
\end{abstract}

Keywords: Electric field, Galvanotaxis, Cell stimulation, Biophysical cues

\section{Background}

Endogenous electric fields (EFs) are involved in the organisation and development of tissues, as well as in their regeneration following injury $[1,2]$. Disruption of endogenous EFs leads to abnormalities [3, 4] and slows down wound healing processes [5]. Physiologically speaking, for example, a polarised epithelium transports ions that maintain a transepithelial potential [6]. When an injury occurs, the transepithelial potential is severely disrupted and an endogenic wound $\mathrm{EF}$ occurs that drives epithelial cells to the wound for healing purposes [7]. The magnitude of endogenous EFs varies as a function of species, tissue, location and developmental stage [e.g. 0.02-0.04 V/cm during neocortical activity in ferrets [8]; $0.1-0.2 \mathrm{~V} / \mathrm{cm}$ in different anatomical parts of axolotl embryos during their developmental stages [9]; $0.42 \mathrm{~V} / \mathrm{cm}$ in wounded rat corneas [10]; $0.42 \mathrm{~V} / \mathrm{cm}$ in sliced tips of hindlimb digit of Notophthalmus viridescens [11]; $1.1-1.8 \mathrm{~V} / \mathrm{cm}$ in wounded mouse and

\footnotetext{
*Correspondence: dimitrios.zeugolis@usi.ch

${ }^{+}$Christina N.M. Ryan and Meletios N. Doulgkeroglou shared first authorship. ${ }^{1}$ Regenerative, Modular \& Developmental Engineering Laboratory (REMODEL), National University of Ireland Galway \& USI, Galway, Ireland ${ }^{2}$ Science Foundation Ireland (SFI) Centre for Research in Medical Devices (CÚRAM), National University of Ireland Galway, Galway, Ireland

Full list of author information is available at the end of the article
}

human skin [12]; $1-2 \mathrm{~V} / \mathrm{cm}$ in small skin cuts of cavies [13]; 20-30 mV/cm in mice brain [14].

Considering the importance of EFs in physiological tissue function; disease manifestation and progression; and regeneration, research efforts have been directed towards utilising EFs to study cell response in vitro as a means to better understand the mechanism of action of EFinduced stimulation and develop functional therapeutic interventions. It has now become apparent that EF stimulation in vitro modulates cell morphology, orientation, migration and phenotype commitment, as well as extracellular matrix (ECM) synthesis and orientation $[15,16]$ and in vivo promotes ECM synthesis [17], modulates ECM deposition [18] and accelerates wound healing [19]. To describe the influence of EF stimulation on cell response, the theories of galvanotaxis (i.e. the process of preferential cell migration towards the anode or the cathode) and galvanotropism (i.e. changes in cell morphology) have been introduced [20, 21]. Over the years, various EF apparati have been used to study the influence of EF stimulation on cell response in vitro with variable degree of complexity and efficiency, jeopardising comprehensive investigation of this in vitro microenvironment modulator. Thus, this review provides and overview of EF setups, describes the function of their most

(c) The Author(s). 2020 Open Access This article is licensed under a Creative Commons Attribution 4.0 International License, which permits use, sharing, adaptation, distribution and reproduction in any medium or format, as long as you give appropriate credit to the original author(s) and the source, provide a link to the Creative Commons licence, and indicate if changes were made. The images or other third party material in this article are included in the article's Creative Commons licence, unless indicated otherwise in a credit line to the material. If material is not included in the article's Creative Commons licence and your intended use is not permitted by statutory regulation or exceeds the permitted use, you will need to obtain permission directly from the copyright holder. To view a copy of this licence, visit http://creativecommons.org/licenses/by/4.0/ The Creative Commons Public Domain Dedication waiver (http://creativecommons.org/publicdomain/zero/1.0/) applies to the data made available in this article, unless otherwise stated in a credit line to the data. 
important components and discusses advancements and shortfalls in EF stimulation in controlling cell function.

\section{Main text}

\section{Electric field cell stimulation setups}

In vitro EF stimulation started with a simple setup, where two electrodes were placed at the bottom of a cell culture well and the cells were seeded in between (Fig. 1a). Trial and error experiments (e.g. to avoid media evaporation, avoid electrode degradation products contaminating the cells) have resulted in the current setup, which includes a chamber that contains the media and the cells, with agar bridges transferring the charge from the electrodes immersed into electrolytes to the cell media (Fig. 1b). In the spirit of automation and scalability, parallel setups [22] have been developed that allow for multiple experiments to be conducted simultaneously (Fig. 1c). More complex systems, such as bioreactors capable of combining EF stimulation with mechanical loads [23], have also been developed (Fig. 1d). In the era of miniaturisation, compact, closedsystem microfluidic devices (Fig. 1e) that provide more effective control over the uniformity of the EF, mitigate the Joule heating effect, reduce the dimensionality of equipment and offer high data output have also been realised $[24,25]$.

Independently of the setup, poly(methyl methacrylate) (PMMA) [26-29] and poly(dimethylsiloxane) (PDMS) [30-36] are mostly used for the fabrication of galvanotaxis devices, although some devices have been made from glass [33] or plastic [37]. Further, all systems have a window (usually a glass slide / coverslip), which allows visual assessment of cells before, during and after EF stimulation [38-40]. When chamber size permits, the entire chamber is placed on the stage of an inverted microscope and cell behaviour is observed directly during experiments [41-46]. In the subsequent sections the main components of most EF cell stimulation apparatus are discussed.

\section{Galvanotaxis chamber}

Galvanotaxis chambers are constructed to allow flow of constant electric current directly over the cells within a channel. An early study used a trough that was created by placing two parallel glass coverslips in the centre of a petri dish. The cells were seeded in the created trough and a closed EF was created by connecting the cell culture media with the agar salt bridges to the solution with the electrodes [47]. Due to this simple construction, similar chambers composed of glass slides or coverslips separated by acetate or silicon spacers and held together with silicone grease or adhesive have been fabricated [48-54]. To reduce time, effort and costs associated with continuous chamber fabrication, a modular chamber design comprised of parallel plates that allow glass slides or coverslips plated with cells to be inserted and removed at ease without affecting the chamber structure have been developed using various materials (e.g. plexiglass, polycarbonate, acrylic, graphene and PMMA) [5561]. PDMS is featured in several setups either as a primary material from which chambers may be excised [62] or due to its insulating properties that allow independent
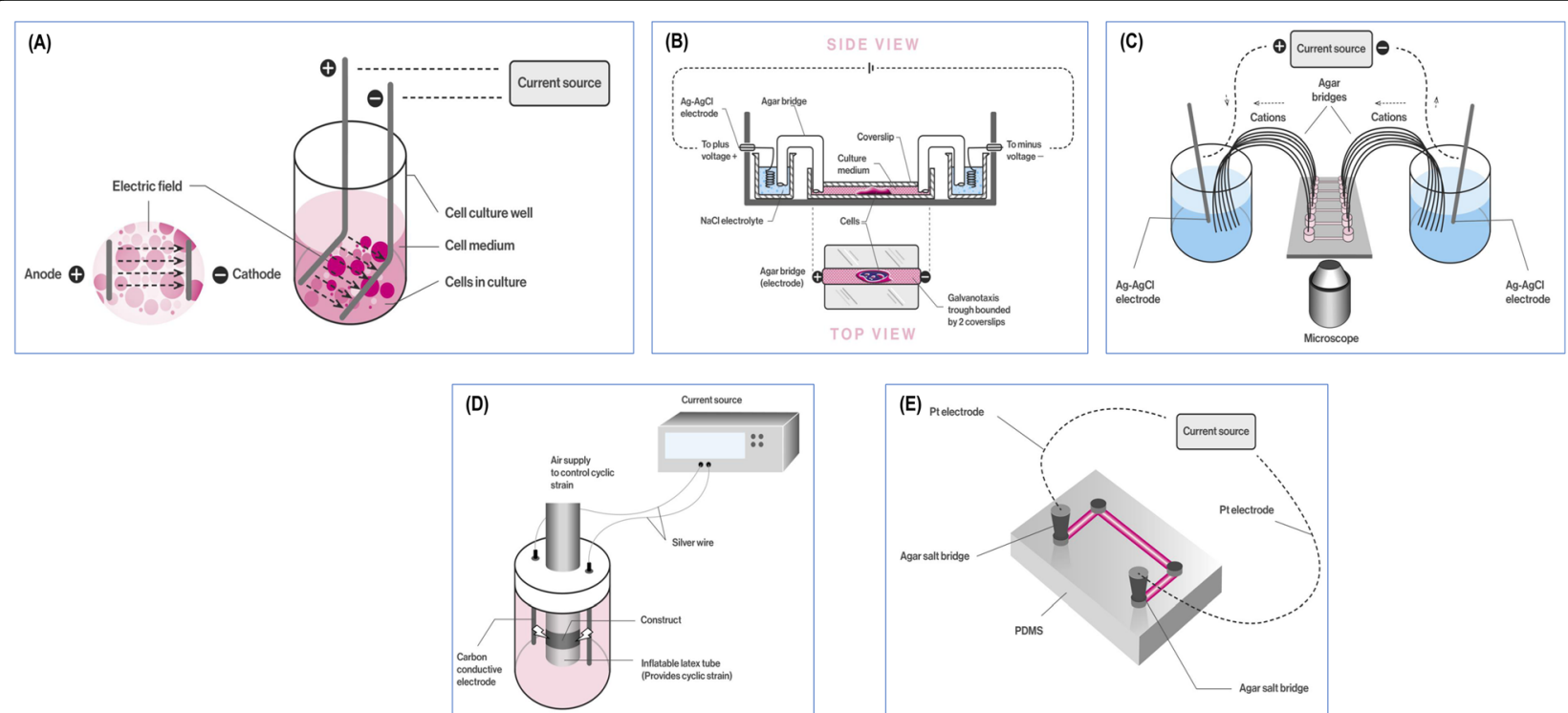

Fig. 1 Schematic illustration of various galvanotaxis setups. a The simplest setup. b The most common setup. c Parallel setup that allows multiple experiment simultaneously. $\mathbf{d}$ Multifactorial setup that allows simultaneous application of electric field stimulation and mechanical loading. $\mathbf{e}$ Miniaturised, closed system microfluidic setup 
electrical stimulation of rows of wells [63]. Further, its versatility of stiffness modification [64], allows for simultaneous assessment of substrate rigidity and EF stimulation on cell response. To assist cell adhesion, surfaces used as channels for cell seeding are often coated with ECM proteins (e.g. laminin, fibronectin, collagen) [65$70]$ and to improve cell motility and alignment, microgrooves are etched onto glass / quartz slides [71-73].

\section{Electrodes}

Electric current is generally passed through the galvanotaxis chamber by placing electrodes into phosphate buffered saline (PBS) or Steinberg's solution reservoirs, from which agarose salt bridges form a conducting pathway to the chamber with the cathode connected at one side of the chamber and the anode to the other [46, 47]. Conductive bridges, composed of plastic or glass tubing are filled with agarose (2-4\%) and can be of different lengths [from $6 \mathrm{~cm}[74,75]$ to $35 \mathrm{~cm}[55,59]$, although most setups incorporate bridges of 15 to $20 \mathrm{~cm}$ [76-78]]. Some groups have even bent tissue culture pipettes into U-shapes and used them as agar-salt bridges, which have the added advantage of already being sterile [79]. Systems with reduced size agar bridges embedded within the galvanotaxis chamber $[35,36]$ or even setups without salt bridges, which facilitate the design of reduced size devices [80] have also been reported, albeit not extensively. The bridges also act as safeguards to reduce heat exposure of cells via Joule heating of the chamber [75] and prevent electrolysis products (e.g. metal ions) [81] produced at the electrodes from contaminating cells within the chamber [82]. Aluminium [83], carbon [84, 85], copper [86, 87], platinum $[60,88]$ and stainless-steel $[89,90]$ have been used as electrodes across a range of direct current (DC) EF stimulation systems, however silver-silver chloride $(\mathrm{Ag} / \mathrm{AgCl})$ electrodes are the most commonly used [46, 47]. These are favoured as the only species involved in the electrochemical reactions at the electrode surface are chloride ions, thus eliminating unwanted reactions associated with electrodes, such as platinum [91]. They convert electron flow to a chloride ion flow from the cathode to the anode through the conducting pathways. $\mathrm{Ag} / \mathrm{AgCl}$ electrodes can be fabricated from silver wire by soaking for up to $1 \mathrm{~h}$ in a hypochlorite / bleach solution, or in $1 \mathrm{M} \mathrm{HCl}$ and then chloridised for $30 \mathrm{~min}$ at a current of $5-10 \mathrm{~mA} \mathrm{~cm}^{2}[59,91]$. These electrodes can then be stored in distilled water or PBS for several weeks. In some setups, the electrodes have been integrated into the galvanotaxis chamber by coiling them about $5 \mathrm{~cm}$ into agarose embedded within the platform [91]. This saving in size of the setup allows the platform to be efficiently placed within a live cell chamber, whereby humidity, $\mathrm{CO}_{2}$ partial pressure and temperature can be controlled relatively ease.
Power supply and electric field stimulation regimes

EF stimulation utilises either DC or alternating current (AC). DC is a steady mono-flow / unidirectional current, whereas $\mathrm{AC}$ has a sinusoidal form and constantly switches direction. As in the extracellular space of plants and animals, DC signals are primarily observed [92], the vast majority of EF cell stimulation studies use DC. Nonetheless, AC has also been selected to either compare its effect with the frequently used DC stimulation [93], or to recreate physiological EFs, in the case of the central nervous system that neurons are exposed to oscillating endogenous EFs [94, 95]. Over the years, numerous cell types have been exposed to different EF strengths $(0-10 \mathrm{~V} / \mathrm{cm})$ and stimulation duration $(0-72$ h) (Table 1). To achieve the required EF strength, DC power supplies (e.g. Keithley SourceMeter ${ }^{\circ}$ ) have been used that work with DC currents of $0.0-0.3 \mathrm{~mA}$ and generate EFs of $0-6 \mathrm{~V} / \mathrm{cm}$ [97, 98]. Eight-channel programmable power simulators (e.g. Master-8, AMPI) [61] generating EFs up to $4.5 \mathrm{~V} / \mathrm{cm}$, multi-potentiostats (e.g. CH1040A, CH Instruments) generating EFs of 0.1 $\mathrm{V} / \mathrm{cm}$ and currents of $0.0-0.1 \mathrm{~mA}$ [86] and the commonly found in laboratory setups gel electrophoresis (e.g. FB600, Thermo Fisher Scientific) power sources $[58,99]$ have also been used with an EF range of $0-10$ $\mathrm{V} / \mathrm{cm}$. For the measurement and adjustment of current and field strength during a stimulation, multi-meters can be positioned respectively in series and in parallel with the chamber [55]. In addition, current density and correlating EFs have been altered not only by adjusting applied current or voltage, but also by altering resistance through the channel by varying the channel widths $(0.5-3.0 \mathrm{~cm})$ [86]. For the application of AC EFs, function (waveform) generators that provide both type of currents may be used (e.g. Precision 4011A, PASCO Scientific) [93] with the AC component ranging less than the regimes observed in $\mathrm{DC}$, usually within $0-1 \mathrm{~V} / \mathrm{cm}[58,100]$.

\section{Generated forces during a galvanotaxis experiment}

When a cell migrates in any substrate, its displacement gives rise to three-dimensional tractional forces [101], which is also the case for EF assisted migration. During EF stimulation, cells are exposed to forces from the EF itself and from the culture substrate. The stress can be perpendicular and horizontal to the direction of the EF. Forces also develop between the surfaces of the cells, as they touch each other in the restricted space of a galvanotaxis chamber during a collective migration. The interaction of the cells leads to a parallel to the direction shear stress and a perpendicular to the direction normal stress [102]. It has been shown that by the onset of EF in a keratinocyte monolayer [103], the intercellular stress component in the perpendicular axis to the EF direction increases significantly in comparison to the stress 


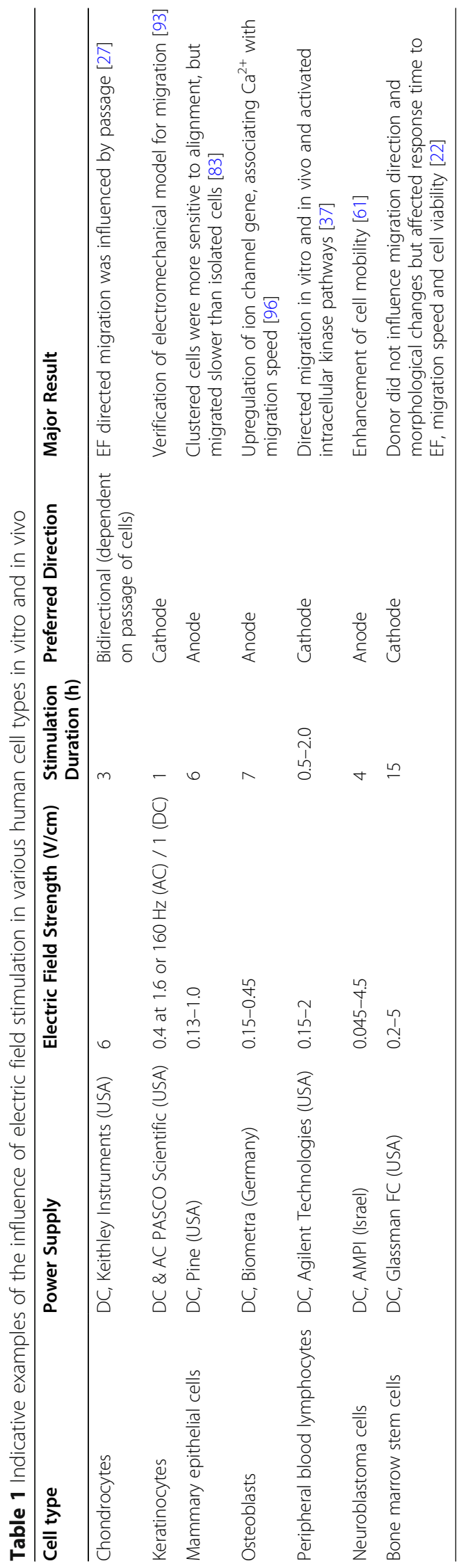


component in parallel to the EF direction and that migration is independent of the reorientation of the intercellular stress. In addition, the flow, which can be hypothesised as laminar, applies hydrodynamic forces to the cells. These forces can be calculated by the hydrodynamic equation of laminar flow mechanics.

The exact mechanism regarding galvanotaxis-induced motility is still unclear. In literature, different hypotheses have been formulated regarding the decisive factor for cell migration during galvanotaxis. These hypotheses include the effect of flow, due to hydrodynamic cell forces, on the cell membrane [104]; the activation of electrotaxis, owed to change of cell membrane polarity, which in turn is driven by an asymmetric local concentration of ions [105]; and the electrophoresis of charged membrane components (e.g. proteins) [106, 107]. The normally occurring hydrodynamic forces alone have not been proven to contribute to directional migration, since cells were observed to move randomly in the absence of an EF in almost all the reported experiments [54, 103] However, when an external shear stress stimuli was applied, migration was retained in the preferential direction even without the application of an EF [35]. A recent work investigated the role of integrins by testing hamster ovary modified cell lines that express specific human integrins and concluded that different subsets of integrins may promote normal or reverse directional migration during galvanotaxis, thus highlighting the importance of the intracellular domain with cell migration [108]. It should be noted that the strength of the EF increases the aligned directed locomotion of the cells, as it has been shown in numerical simulations [109] and experimental data $[110,111]$. However, differences were observed [83] in the time of response and the required EF intensity needed to trigger migration for clustered and isolated cells. It should be noted that according to the cell type, cells may show different preferences in anodal or cathodal directed migration (Table 1).

\section{Electric field stimulation in vitro and in vivo}

Although the influence of DC and AC EFs on cell response in vitro and in vivo has been the subject of many investigations (Table 1), it is worth noting that most studies focus on the alignment and migration patterns that DC EFs induce to cells and only a few studies have assessed the influence of EFs on cellular functions in vitro and tissue response in vivo. In general, subject to the cell population, DC EF of up to $10 \mathrm{~V} / \mathrm{cm}$ and for up to $72 \mathrm{~h}$ are efficient in controlling cell orientation and migration [71, 72], increase cell proliferation [112, 113]; and do not affect cell metabolic activity and viability [114-117]. Stem cell differentiation has also been studied; for example, DC EFs of $0.1-1.0 \mathrm{~V} / \mathrm{cm}[118,119]$ and pulsed DC EFs of $50 \mathrm{~Hz}$ and $6 \mathrm{~V} / \mathrm{cm}$ peak-to-peak amplitude for $6 \mathrm{~h}$ per day [120] have been shown to favour osteogenic differentiation.

With respect to AC EF stimulation, although it has been shown to affect cellular functions, alone has not been shown consistently to result in controlled cell orientation and migration. For example, AC EFs of 10 $\mathrm{Hz}$ and $50 \mathrm{~Hz}$ have been shown to sustain a more immature phenotype in porcine neural progenitor cells, without promoting alignment and affecting proliferation [100]. AC EF stimulation $(20 \mathrm{mV} / \mathrm{cm}, 60 \mathrm{kHz}, 40 \mathrm{~min}$ per day for 20 days) has also been shown to not affect cell morphology and metabolic activity in human stem cell cultures and to increase osteogenic differentiation [121]. Regarding differentiation, AC EFs have been used for both osteogenic [122-124] and chondrogenic [125, 126] differentiation of stem cells. When mouse neural stem cells were encapsulated in alginate hydrogel beads and subjected to AC EFs $(0.1$ to $10 \mathrm{~Hz} ; 2,4,16 \mathrm{~V} / \mathrm{m} ; 14$ and 21 days), it was reported that $1 \mathrm{~Hz}$ frequency enhanced viability, whilst differentiation was promoted or inhibited subject to culture time and EF frequency (cell morphology analysis was not conducted) [127].

When DC was directly compared to AC in rat neural stem/progenitor cell cultures, it was found that differentiation and migration were enhanced and viability was decreased in DC EFs, whilst AC EF had no effect [58]. Interestingly, in human keratinocytes isolated from neonatal foreskin cultures, AC led to random migration; DC alone and $\mathrm{DC}$ combined with $\mathrm{AC}$ resulted in cathodal direction; and DC combined with $160 \mathrm{~Hz}$ AC resulted in enhanced migration in comparison to $\mathrm{DC}$ alone and $\mathrm{DC}$ combined with $1.6 \mathrm{~Hz}$ AC [93]. Other than cell morphology and migration analysis studies, more in depth biological analysis studies are required to clearly illustrate whether there are any beneficial effects in combing DC with AC EF stimulation.

In in vivo setting, preliminary studies advocate the use of EF stimulation. For example, the migration of human peripheral blood lymphocytes was enhanced in mouse ear skin model when an external EF was applied [37]. EFs have also been shown to promote migration and differentiation of neural progenitor cells in a rat model of chronic-phase ischemic stroke [128]. In a similar manner, electrodes were inserted in a rat brain and stimulated transplanted human neural progenitor cells, resulting in directed migration and increased motility [129]. Furthermore, transvaginal electric stimulation in female mice has shown activation and proliferation of fibroblasts [130].

In clinical setting, electric stimulation has been used in different instances with mixed outcomes. Recent studies, for example, include the use of electric stimulation to treat neurogenic bowel dysfunction in patients that suffered spinal cord injuries, but without consistent results 
[131]. On the other hand, EF stimulation resulted in a reliable recovery of motor functions in patients experienced a stroke [132], an improvement in visual abilities by the placement skin electrodes in patients with retinitis pigmentosa [133] and accelerated wound healing [19], collectively indicating the potential of EF stimulation in reparative medicine.

\section{Conclusions}

Electric field stimulation is continuously gaining pace as a means to control cell orientation, migration and phenotype in vitro and in vivo. Direct current electric fields (up to $10 \mathrm{~V} / \mathrm{cm}$ ) are favoured among investigators, as such signals are primarily encountered in the extracellular space of plants and animals. Although variable in complexity galvanotaxis chambers have been used over the years, the most popular setups are comprised of glass slides for cell seeding, transparent polymers that allow real-time cell visualisation, $\mathrm{Ag} / \mathrm{AgCl}$ electrodes that eliminate toxic electrode degradation products and agarose salt bridges in phosphate buffered saline to prevent them from drying and to stabilise electrode potentials. It is worth noting that despite the promising in vitro data, only a few studies have assessed the influence of electric field stimulation in vivo and in clinical setting. Standardisation and automation of the processes will allow more intense investigation of electric field stimulation in the years to come.

\section{Abbreviations}

AC: Alternating current; Ag/AgCl: Silver-silver chloride; DC: Direct current; EF: Electric field; ECM: Extracellular matrix; PBS: Phosphate buffered saline; PDMS: Poly(dimethylsiloxane); PMMA: Poly(methylmethacrylate)

\section{Acknowledgments}

Not applicable.

\section{Authors' contributions}

CNMR, MND and DIZ wrote, edited and approved the manuscript. CNMR and MND equally share first authorship. The author(s) read and approved the final manuscript.

\section{Funding}

This work has been supported by Science Foundation Ireland, Career Development Award (Grant Agreement Number: 15/CDA/3629) and Science Foundation Ireland / European Regional Development Fund (Grant Agreement Number: 13/RC/2073). This work has also received funding from the European Research Council (ERC) under the European Union's Horizon 2020 research and innovation programme, grant agreement No. 866126. The funding agencies were not involved in the design of the study; in the data collection, analysis and interpretation; and in the writing of the manuscript.

\section{Availability of data and materials}

Not applicable.

\section{Ethics approval and consent to participate}

Not applicable.

\section{Consent for publication}

Not applicable.

\section{Competing interests}

The authors declare that they have no competing interests.

\section{Author details}

${ }^{1}$ Regenerative, Modular \& Developmental Engineering Laboratory (REMODEL), National University of Ireland Galway \& USI, Galway, Ireland.

${ }^{2}$ Science Foundation Ireland (SFI) Centre for Research in Medical Devices (CÚRAM), National University of Ireland Galway, Galway, Ireland.

${ }^{3}$ Regenerative, Modular \& Developmental Engineering Laboratory (REMODEL), Faculty of Biomedical Sciences, Università della Svizzera Italiana (USI), Lugano, Switzerland.

Received: 30 June 2020 Accepted: 6 December 2020

Published online: 05 January 2021

\section{References}

1. Colello RJ, Alexander JK. Electrical fields: Their nature and influence on biological systems. In: Morkoç H, editor. Advanced semiconductor and organic nano-techniques; 2003. p. 319-46.

2. Rajnicek AM, Stump RF, Robinson KR. An endogenous sodium current may mediate wound healing in Xenopus neurulae. Dev Biol. 1988;128(2):290-9.

3. Borgens RB, Vanable JW Jr, Jaffe LF. Reduction of sodium dependent stump currents disturbs urodele limb regeneration. J Exp Zool. 1979;209(3):377-86.

4. Jenkins LS, Duerstock BS, Borgens RB. Reduction of the current of injury leaving the amputation inhibits limb regeneration in the red spotted newt. Dev Biol. 1996:178(2):251-62.

5. Chiang MC, Cragoe EJ Jr, Vanable JW Jr. Intrinsic electric fields promote epithelization of wounds in the newt, Notophthalmus viridescens. Dev Biol. 1991;146(2):377-85.

6. Zhao M. Electrical fields in wound healing - an overriding signal that directs cell migration. Semin Cell Dev Biol. 2009;20(6):674-82.

7. Tran V, Zhang X, Cao L, Li H, Lee B, So M, et al. Synchronization modulation increases transepithelial potentials in MDCK monolayers through $\mathrm{Na} / \mathrm{K}$ pumps. PLoS One. 2013;8(4):e61509.

8. Fröhlich F, McCormick DA. Endogenous electric fields may guide neocortical network activity. Neuron. 2010;67(1):129-43.

9. Shi R, Borgens RB. Three-dimensional gradients of voltage during development of the nervous system as invisible coordinates for the establishment of embryonic pattern. Dev Dyn. 1995;202(2):101-14.

10. Reid B, Song B, McCaig CD, Zhao M. Wound healing in rat cornea: the role of electric currents. FASEB J. 2005;19(3):379-86.

11. Chiang M, Cragoe EJ Jr, Vanable JW Jr. Electrical fields in the vicinity of small wounds in Notophthalmus viridescens skin. Biol Bull. 1989;176(2S): 179-83.

12. Nuccitelli $R$, Nuccitelli $P$, Ramlatchan $S$, Sanger $R$, Smith PJ. Imaging the electric field associated with mouse and human skin wounds. Wound Repair Regen. 2008;16(3):432-41.

13. Barker AT, Jaffe LF, Vanable JW Jr. The glabrous epidermis of cavies contains a powerful battery. Am J Phys. 1982;242(3):R358-66.

14. Cao L, Wei D, Reid B, Zhao S, Pu J, Pan T, et al. Endogenous electric currents might guide rostral migration of neuroblasts. EMBO Rep. 2013;14(2):184-90.

15. Hiemer B, Krogull M, Bender T, Ziebart J, Krueger S, Bader R, et al. Effect of electric stimulation on human chondrocytes and mesenchymal stem cells under normoxia and hypoxia. Mol Med Rep. 2018;18(2):2133-41.

16. Vaca-González J, Guevara J, Vega J, Garzón-Alvarado D. An in vitro chondrocyte electrical stimulation framework: a methodology to calculate electric fields and modulate proliferation, cell death and glycosaminoglycan synthesis. Cell Mol Bioeng. 2016;9(1):116-26

17. Lirani-Galvao AP, Bergamaschi CT, Silva OL, Lazaretti-Castro M. Electrical field stimulation improves bone mineral density in ovariectomized rats. Braz J Med Biol Res. 2006;39(11):1501-5.

18. Oliveira KMC, Barker JH, Berezikov E, Pindur L, Kynigopoulos S, EischenLoges $M$, et al. Electrical stimulation shifts healing/scarring towards regeneration in a rat limb amputation model. Sci Rep. 2019;9(1):11433.

19. Thakral G, Lafontaine J, Najafi B, Talal TK, Kim P, Lavery LA. Electrical stimulation to accelerate wound healing. Diabet Foot Ankle. 2013;4. https:// doi.org/10.3402/dfa.v4i0.22081. PMID: 24049559; PMCID: PMC3776323.

20. Robinson KR. The responses of cells to electrical fields: a review. J Cell Biol. 1985;101(6):2023-7.

21. Nuccitelli R. A role for endogenous electric fields in wound healing. Curr Top Dev Biol. 2003;58:1-26. 
22. Banks TA, Luckman PS, Frith JE, Cooper-White JJ. Effects of electric fields on human mesenchymal stem cell behaviour and morphology using a novel multichannel device. Integr Biol (Camb). 2015;7(6):693-712.

23. Morgan KY, Black LD III. Mimicking isovolumic contraction with combined electromechanical stimulation improves the development of engineered cardiac constructs. Tissue Eng Part A. 2014;20(11-12):1654-67.

24. Sun YS. Studying electrotaxis in microfluidic devices. Sensors (Basel). 2017; 17(9):2048. https://doi.org/10.3390/s17092048. PMID: 28880251; PMCID: PMC5621068.

25. Li J, Lin F. Microfluidic devices for studying chemotaxis and electrotaxis. Trends Cell Biol. 2011;21(8):489-97.

26. Hou HS, Chang HF, Cheng JY. Electrotaxis studies of lung cancer cells using a multichannel dual-electric-field microfluidic chip. J Vis Exp. 2015;106: e53340

27. O'Connell GD, Tan AR, Cui V, Bulinski JC, Cook JL, Attur M, et al. Human chondrocyte migration behaviour to guide the development of engineered cartilage. J Tissue Eng Regen Med. 2017;11(3):877-86.

28. Wang CC, Kao YC, Chi PY, Huang CW, Lin JY, Chou CF, et al. Asymmetric cancer-cell filopodium growth induced by electric-fields in a microfluidic culture chip. Lab Chip. 2011;11(4):695-9.

29. Simpson MJ, Lo KY, Sun YS. Quantifying the roles of random motility and directed motility using advection-diffusion theory for a 3T3 fibroblast cell migration assay stimulated with an electric field. BMC Syst Biol. 2017;11(1): 39.

30. Zhao S, Zhu K, Zhang Y, Zhu Z, Xu Z, Zhao M, et al. ElectroTaxis-on-a-Chip (ETC): an integrated quantitative high-throughput screening platform for electrical field-directed cell migration. Lab Chip. 2014;14(22):4398-405.

31. Li Y, Xu T, Zou H, Chen X, Sun D, Yang M. Cell migration microfluidics for electrotaxis-based heterogeneity study of lung cancer cells. Biosens Bioelectron. 2017:89(Pt 2):837-45.

32. Li J, Zhu L, Zhang M, Lin F. Microfluidic device for studying cell migration in single or co-existing chemical gradients and electric fields. Biomicrofluidics. 2012;6(2):24121-2412113

33. Li J, Nandagopal S, Wu D, Romanuik SF, Paul K, Thomson DJ, et al. Activated T lymphocytes migrate toward the cathode of DC electric fields in microfluidic devices. Lab Chip. 2011;11(7):1298-304.

34. Rio M, Bola S, Funk RHW, Gerlach G. Microfluidic measurement of cell motility in response to applied non-homogeneous DC electric fields. J Sens Sens Syst. 2016;5(2):237-43.

35. Song $\mathrm{S}, \mathrm{Han} \mathrm{H}, \mathrm{Ko} \cup \mathrm{H}$, Kim J, Shin JH. Collaborative effects of electric field and fluid shear stress on fibroblast migration. Lab Chip. 2013;13(8):1602-11.

36. Huang YJ, Schiapparelli P, Kozielski K, Green J, Lavell E, Guerrero-Cazares H, et al. Electrophoresis of cell membrane heparan sulfate regulates galvanotaxis in glial cells. J Cell Sci. 2017;130(15):2459-67.

37. Lin F, Baldessari F, Gyenge CC, Sato T, Chambers RD, Santiago JG, et al. Lymphocyte electrotaxis in vitro and in vivo. J Immunol. 2008;181(4):246571.

38. Finkelstein El, Chao PH, Hung CT, Bulinski JC. Electric field-induced polarization of charged cell surface proteins does not determine the direction of galvanotaxis. Cell Motil Cytoskeleton. 2007;64(11):833-46.

39. Tsai $\mathrm{CH}$, Lin BJ, Chao PH. alpha2beta1 integrin and RhoA mediates electric field-induced ligament fibroblast migration directionality. J Orthop Res. 2013;31(2):322-7.

40. Tan AR, Alegre-Aguaron E, O'Connell GD, VandenBerg CD, Aaron RK, VunjakNovakovic G, et al. Passage-dependent relationship between mesenchymal stem cell mobilization and chondrogenic potential. Osteoarthr Cartil. 2015; 23(2):319-27.

41. Babona-Pilipos R, Pritchard-Oh A, Popovic MR, Morshead CM. Biphasic monopolar electrical stimulation induces rapid and directed galvanotaxis in adult subependymal neural precursors. Stem Cell Res Ther. 2015;6:67.

42. Dube J, Rochette-Drouin O, Levesque P, Gauvin R, Roberge CJ, Auger FA, et al. Human keratinocytes respond to direct current stimulation by increasing intracellular calcium: preferential response of poorly differentiated cells. J Cell Physiol. 2012;227(6):2660-7.

43. Cohen DJ, Nelson WJ, Maharbiz MM. Galvanotactic control of collective cell migration in epithelial monolayers. Nat Mater. 2014;13(4):409-17.

44. Kim MS, Lee MH, Kwon BJ, Seo HJ, Koo MA, You KE, et al. Control of neonatal human dermal fibroblast migration on poly(lactic-co-glycolic acid)-coated surfaces by electrotaxis. J Tissue Eng Regen Med. 2017; 11(3):862-8.
45. Schopf A, Boehler C, Asplund M. Analytical methods to determine electrochemical factors in electrotaxis setups and their implications for experimental design. Bioelectrochemistry. 2016;109:41-8.

46. Song B, Gu Y, Pu J, Reid B, Zhao Z, Zhao M. Application of direct current electric fields to cells and tissues in vitro and modulation of wound electric field in vivo. Nat Protoc. 2007;2(6):1479-89.

47. Zhao M, Agius-Fernandez A, Forrester JV, McCaig CD. Orientation and directed migration of cultured corneal epithelial cells in small electric fields are serum dependent. J Cell Sci. 1996;109(Pt 6):1405-14.

48. McBain VA, Forrester JV, McCaig CD. HGF, MAPK, and a small physiological electric field interact during corneal epithelial cell migration. Invest Ophthalmol Vis Sci. 2003;44(2):540-7.

49. Alexander JK, Fuss B, Colello RJ. Electric field-induced astrocyte alignment directs neurite outgrowth. Neuron Glia Biol. 2006;2(2):93-103.

50. Bai H, Forrester JV, Zhao M. DC electric stimulation upregulates angiogenic factors in endothelial cells through activation of VEGF receptors. Cytokine. 2011:55(1):110-5.

51. Guo X, Jiang X, Ren X, Sun H, Zhang D, Zhang Q, et al. The galvanotactic migration of keratinocytes is enhanced by hypoxic preconditioning. Sci Rep. 2015;5:10289.

52. Liu J, Yan XL, Zheng XL, Mei L, Wang S, Han J, et al. Electric field exposure promotes epithelial-mesenchymal transition in human lens epithelial cells via integrin beta1-FAK signaling. Mol Med Rep. 2017;16(4):4008-14.

53. Zimolag E, Borowczyk-Michalowska J, Kedracka-Krok S, Skupien-Rabian B, Karnas E, Lasota S, et al. Electric field as a potential directional cue in homing of bone marrow-derived mesenchymal stem cells to cutaneous wounds. BBA Mol Cell Res. 2017;1864(2):267-79.

54. Babona-Pilipos R, Liu N, Pritchard-Oh A, Mok A, Badawi D, Popovic MR, et al. Calcium influx differentially regulates migration velocity and directedness in response to electric field application. Exp Cell Res. 2018;368(2):202-14.

55. Chao PH, Roy R, Mauck RL, Liu W, Valhmu WB, Hung CT. Chondrocyte translocation response to direct current electric fields. J Biomech Eng. 2000; 122(3):261-7.

56. Finkelstein E, Chang W, Chao PH, Gruber D, Minden A, Hung CT, et al. Roles of microtubules, cell polarity and adhesion in electric-field-mediated motility of 3T3 fibroblasts. J Cell Sci. 2004:117(Pt 8):1533-45.

57. Gunja NJ, Dujari D, Chen A, Luengo A, Fong JV, Hung CT. Migration responses of outer and inner meniscus cells to applied direct current electric fields. J Orthop Res. 2012;30(1):103-11.

58. Ariza CA, Fleury AT, Tormos CJ, Petruk V, Chawla S, Oh J, et al. The influence of electric fields on hippocampal neural progenitor cells. Stem Cell Rev Rep. 2010;6(4):585-600.

59. Tandon N, Goh B, Marsano A, Chao PH, Montouri-Sorrentino C, Gimble J, et al. Alignment and elongation of human adipose-derived stem cells in response to direct-current electrical stimulation. Conf Proc IEEE Eng Med Biol Soc. 2009;2009:6517-21.

60. Hammerick KE, Longaker MT, Prinz FB. In vitro effects of direct current electric fields on adipose-derived stromal cells. Biochem Biophys Res Commun. 2010;397(1):12-7.

61. Heo C, Yoo J, Lee SY, Lee S, Joo EY, Hong SB, et al. Enhanced mobility of neural cells with a transparent electric field stimulator. J Nanosci Nanotechnol. 2012;12(7):5222-7.

62. Koppes AN, Seggio AM, Thompson DM. Neurite outgrowth is significantly increased by the simultaneous presentation of Schwann cells and moderate exogenous electric fields. J Neural Eng. 2011;8(4):046023.

63. Serena E, Figallo E, Tandon N, Cannizzaro C, Gerecht S, Elvassore N, et al. Electrical stimulation of human embryonic stem cells: cardiac differentiation and the generation of reactive oxygen species. Exp Cell Res. 2009;315(20): 3611-9.

64. Brown XQ, Ookawa K, Wong JY. Evaluation of polydimethylsiloxane scaffolds with physiologically-relevant elastic moduli: interplay of substrate mechanics and surface chemistry effects on vascular smooth muscle cell response. Biomaterials. 2005;26(16):3123-9.

65. Zhao M, Dick A, Forrester JV, McCaig CD. Electric field-directed cell motility involves up-regulated expression and asymmetric redistribution of the epidermal growth factor receptors and is enhanced by fibronectin and laminin. Mol Biol Cell. 1999;10(4):1259-76.

66. Fang KS, lonides E, Oster G, Nuccitelli R, Isseroff RR. Epidermal growth factor receptor relocalization and kinase activity are necessary for directional migration of keratinocytes in DC electric fields. J Cell Sci. 1999;112(Pt 12): 1967-78. 
67. Grahn JC, Reilly DA, Nuccitelli RL, Isseroff RR. Melanocytes do not migrate directionally in physiological DC electric fields. Wound Repair Regen. 2003; 11(1):64-70

68. Cao L, Pu J, Zhao M. GSK-3beta is essential for physiological electric fielddirected Golgi polarization and optimal electrotaxis. Cell Mol Life Sci. 2011; 68(18):3081-93.

69. Zhu B, Nicholls M, Gu Y, Zhang G, Zhao C, Franklin RJ, Song B. Electric signals regulate the directional migration of Oligodendrocyte Progenitor Cells (OPCs) via $\beta 1$ Integrin. Int J Mol Sci. 2016;17(11):1948. https://doi.org/ 10.3390/ijms17111948. PMID: 27879672; PMCID: PMC5133942.

70. Dong ZY, Pei Z, Li Z, Wang YL, Khan A, Meng XT. Electric field stimulation induced neuronal differentiation of filum terminale derived neural progenitor cells. Neurosci Lett. 2017;651:109-15.

71. Rajnicek AM, Foubister LE, McCaig CD. Alignment of corneal and lens epithelial cells by co-operative effects of substratum topography and DC electric fields. Biomaterials. 2008;29(13):2082-95.

72. Zhao M, Bai H, Wang E, Forrester JV, McCaig CD. Electrical stimulation directly induces pre-angiogenic responses in vascular endothelial cells by signaling through VEGF receptors. J Cell Sci. 2004;117(Pt 3):397-405.

73. Gibson IR, McCaig CD. Competitive guidance cues affect fibroblast cell alignment: electric fields vs. contact guidance. Mater Res Soc Symp Proc. 2005;845:31-6.

74. Trollinger DR, Isseroff RR, Nuccitelli R. Calcium channel blockers inhibit galvanotaxis in human keratinocytes. J Cell Physiol. 2002;193(1):1-9.

75. Nishimura KY, Isseroff RR, Nuccitelli R. Human keratinocytes migrate to the negative pole in direct current electric fields comparable to those measured in mammalian wounds. J Cell Sci. 1996;109(Pt 1):199-207.

76. Chen Y, Ye L, Guan L, Fan P, Liu R, Liu H, Chen J, Zhu Y, Wei X, Liu Y, Bai H. Physiological electric field works via the VEGF receptor to stimulate neovessel formation of vascular endothelial cells in a 3D environment. Biol Open. 2018;7(9):bio035204. https://doi.org/10.1242/bio.035204. PMID: 30232195: PMCID: PMC6176943.

77. Han J, Yan XL, Han QH, Li Y, Zhu J, Hui YN. Electric fields contribute to directed migration of human retinal pigment epithelial cells via interaction between F-actin and beta1 integrin. Curr Eye Res. 2009;34(6):438-46.

78. Ozkucur N, Monsees TK, Perike S, Do HQ, Funk RH. Local calcium elevation and cell elongation initiate guided motility in electrically stimulated osteoblast-like cells. PLoS One. 2009:4(7):e6131.

79. Baer ML, Henderson SC, Colello RJ. Elucidating the role of injury-induced electric fields (EFs) in regulating the astrocytic response to injury in the mammalian central nervous system. PLoS One. 2015;10(11):e0142740.

80. Cole J, Gagnon Z. A flow-based microfluidic device for spatially quantifying intracellular calcium ion activity during cellular electrotaxis. Biomicrofluidics. 2019;13(6):064107

81. Merrill DR, Bikson M, Jefferys JG. Electrical stimulation of excitable tissue: design of efficacious and safe protocols. J Neurosci Methods. 2005;141(2):171-98.

82. Xiong GM, Do AT, Wang JK, Yeoh CL, Yeo KS, Choong C. Development of a miniaturized stimulation device for electrical stimulation of cells. J Biol Eng. 2015;9:14.

83. Lalli ML, Asthagiri AR. Collective migration exhibits greater sensitivity but slower dynamics of alignment to applied electric fields. Cell Mol Bioeng. 2015;8(2):247-57.

84. Lin BJ, Tsao SH, Chen A, Hu SK, Chao L, Chao PG. Lipid rafts sense and direct electric field-induced migration. Proc Natl Acad Sci U S A. 2017; 114(32):8568-73.

85. Long H, Yang G, Wang Z. Galvanotactic migration of EA.Hy926 endothelial cells in a novel designed electric field bioreactor. Cell Biochem Biophys. 2011;61(3):481-91.

86. Nguyen HT, Sapp S, Wei C, Chow JK, Nguyen A, Coursen J, Luebben S, Chang E, Ross R, Schmidt CE. Electric field stimulation through a biodegradable polypyrrole-co-polycaprolactone substrate enhances neural cell growth. J Biomed Mater Res A. 2014;102(8):2554-64. https://doi.org/10. 1002/jbm.a.34925. Epub 2013 Sep 2. PMID: 23964001; PMCID: PMC3931748.

87. Wang X, Gao Y, Shi H, Liu N, Zhang W, Li H. Influence of the intensity and loading time of direct current electric field on the directional migration of rat bone marrow mesenchymal stem cells. Front Med (Lausanne). 2016; 10(3):286-96.

88. Liu M, Yin C, Jia Z, Li K, Zhang Z, Zhao Y, et al. Protective effect of moderate exogenous electric field stimulation on activating Netrin-1/DCC expression against mechanical stretch-induced injury in spinal cord neurons. Neurotox Res. 2018;34(2):285-94
89. Nguyen HT, Wei C, Chow JK, Nguy L, Nguyen HK, Schmidt CE. Electric field stimulation through a substrate influences Schwann cell and extracellular matrix structure. J Neural Eng. 2013;10(4):046011.

90. Ravikumar K, Kar G, Bose S, Basu B. Synergistic effect of polymorphism, substrate conductivity and electric field stimulation towards enhancing muscle cell growth in vitro. RSC Adv. 2016;6:10837-45.

91. Huang YJ, Samorajski J, Kreimer R, Searson PC. The influence of electric field and confinement on cell motility. PLoS One. 2013;8(3):e59447.

92. McCaig CD, Song B, Rajnicek AM. Electrical dimensions in cell science. J Cell Sci. 2009;122(Pt 23):4267-76.

93. Hart FX, Laird M, Riding A, Pullar CE. Keratinocyte galvanotaxis in combined DC and AC electric fields supports an electromechanical transduction sensing mechanism. Bioelectromagnetics. 2013;34(2):85-94.

94. Shapiro S, Borgens R, Pascuzzi R, Roos K, Groff M, Purvines S, et al. Oscillating field stimulation for complete spinal cord injury in humans: a phase 1 trial. J Neurosurg Spine. 2005;2(1):3-10.

95. Kato I, Innami K, Sakuma K, Miyakawa H, Inoue M, Aonishi T. Frequencydependent entrainment of spontaneous Ca transients in the dendritic tufts of CA1 pyramidal cells in rat hippocampal slice preparations by weak AC electric field. Brain Res Bull. 2019;153:202-13.

96. Rohde M, Ziebart J, Kirschstein T, Sellmann T, Porath K, Kuhl F, et al. Human osteoblast migration in DC electrical fields depends on store operated $\mathrm{Ca}(2+)$-release and is correlated to upregulation of stretch-activated TRPM7 channels. Front Bioeng Biotechnol. 2019;7:422.

97. Chao PH, Lu HH, Hung CT, Nicoll SB, Bulinski JC. Effects of applied DC electric field on ligament fibroblast migration and wound healing. Connect Tissue Res. 2007;48(4):188-97.

98. Tandon N, Cannizzaro C, Chao PH, Maidhof R, Marsano A, Au HT, et al. Electrical stimulation systems for cardiac tissue engineering. Nat Protoc. 2009:4(2):155-73.

99. Li X, Kolega J. Effects of direct current electric fields on cell migration and actin filament distribution in bovine vascular endothelial cells. J Vasc Res. 2002;39(5):391-404.

100. Lim JH, McCullen SD, Piedrahita JA, Loboa EG, Olby NJ. Alternating current electric fields of varying frequencies: effects on proliferation and differentiation of porcine neural progenitor cells. Cell Reprogram. 2013;15(5):405-12.

101. Maskarinec SA, Franck C, Tirrell DA, Ravichandran G. Quantifying cellular traction forces in three dimensions. Proc Natl Acad Sci U S A. 2009;106(52):22108-13.

102. Li L, He Y, Zhao M, Jiang J. Collective cell migration: implications for wound healing and cancer invasion. Burns Trauma. 2013;1(1):21-6.

103. Cho Y, Son M, Jeong H, Shin $\mathrm{JH}$. Electric field-induced migration and intercellular stress alignment in a collective epithelial monolayer. Mol Biol Cell. 2018;29(19):2292-302

104. Huang L, Cormie P, Messerli MA, Robinson KR. The involvement of Ca2+ and integrins in directional responses of zebrafish keratocytes to electric fields. J Cell Physiol. 2009;219(1):162-72.

105. Gao RC, Zhang XD, Sun YH, Kamimura Y, Mogilner A, Devreotes PN, et al. Different roles of membrane potentials in electrotaxis and chemotaxis of dictyostelium cells. Eukaryot Cell. 2011:10(9):1251-6.

106. Sun Y, Do H, Gao J, Zhao R, Zhao M, Mogilner A. Keratocyte fragments and cells utilize competing pathways to move in opposite directions in an electric field. Curr Biol. 2013;23(7):569-74.

107. Allen GM, Mogilner A, Theriot JA. Electrophoresis of cellular membrane components creates the directional cue guiding keratocyte galvanotaxis. Curr Biol. 2013:23(7):560-8.

108. Zhu K, Takada Y, Nakajima K, Sun Y, Jiang J, Zhang Y, et al. Expression of integrins to control migration direction of electrotaxis. FASEB J. 2019;33(8): 9131-41.

109. Mousavi SJ, Doweidar MH, Doblare M. 3D computational modelling of cell migration: a mechano-chemo-thermo-electrotaxis approach. J Theor Biol. 2013;329:64-73.

110. Zhao Z, Qin L, Reid B, Pu J, Hara T, Zhao M. Directing migration of endothelial progenitor cells with applied DC electric fields. Stem Cell Res. 2012:8(1):38-48

111. Cunha F, Rajnicek AM, McCaig CD. Electrical stimulation directs migration, enhances and orients cell division and upregulates the chemokine receptors CXCR4 and CXCR2 in endothelial cells. J VasC Res. 2019;56(1):39-53.

112. Li Y, Li X, Zhao R, Wang C, Qiu F, Sun B, et al. Enhanced adhesion and proliferation of human umbilical vein endothelial cells on conductive PANIPCL fiber scaffold by electrical stimulation. Mater Sci Eng C Mater Biol Appl. 2017;72:106-12 
113. Wang Y, Cui H, Wu Z, Wu N, Wang Z, Chen X, et al. Modulation of osteogenesis in MC3T3-E1 cells by different frequency electrical stimulation. PLoS One. 2016;11(5):e0154924.

114. Kobelt LJ, Wilkinson AE, McCormick AM, Willits RK, Leipzig ND. Short duration electrical stimulation to enhance neurite outgrowth and maturation of adult neural stem progenitor cells. Ann Biomed Eng. 2014; 42(10):2164-76.

115. Hoare Jl, Rajnicek AM, McCaig CD, Barker RN, Wilson HM. Electric fields are novel determinants of human macrophage functions. J Leukoc Biol. 2016; 99(6):1141-51.

116. Arnold CE, Rajnicek AM, Hoare Jl, Pokharel SM, McCaig CD, Barker RN, et al. Physiological strength electric fields modulate human T cell activation and polarisation. Sci Rep. 2019;9(1):17604.

117. Zhao Z, Watt C, Karystinou A, Roelofs AJ, McCaig CD, Gibson IR, et al. Directed migration of human bone marrow mesenchymal stem cells in a physiological direct current electric field. Eur Cell Mater. 2011;22:344-58.

118. Sun S, Liu Y, Lipsky S, Cho M. Physical manipulation of calcium oscillations facilitates osteodifferentiation of human mesenchymal stem cells. FASEB J. 2007;21 (7):1472-80.

119. Mobini S, Leppik L, Barker JH. Direct current electrical stimulation chamber for treating cells in vitro. Biotechniques. 2016;60(2):95-8.

120. Hammerick KE, James AW, Huang Z, Prinz FB, Longaker MT. Pulsed direct current electric fields enhance osteogenesis in adipose-derived stromal cells. Tissue Eng Part A. 2010;16(3):917-31.

121. Hronik-Tupaj M, Rice WL, Cronin-Golomb M, Kaplan DL, Georgakoudi I. Osteoblastic differentiation and stress response of human mesenchymal stem cells exposed to alternating current electric fields. Biomed Eng Online. 2011;10:9.

122. Kim IS, Song JK, Song YM, Cho TH, Lee TH, Lim SS, et al. Novel effect of biphasic electric current on in vitro osteogenesis and cytokine production in human mesenchymal stromal cells. Tissue Eng Part A. 2009;15(9):2411-22.

123. Creecy CM, O'Neill CF, Arulanandam BP, Sylvia VL, Navara CS, Bizios R. Mesenchymal stem cell osteodifferentiation in response to alternating electric current. Tissue Eng Part A. 2013;19(3-4):467-74.

124. McCullen SD, McQuilling JP, Grossfeld RM, Lubischer JL, Clarke LI, Loboa EG. Application of low-frequency alternating current electric fields via interdigitated electrodes: effects on cellular viability, cytoplasmic calcium, and osteogenic differentiation of human adipose-derived stem cells. Tissue Eng Part C Methods. 2010;16(6):1377-86.

125. Mardani M, Roshankhah S, Hashemibeni B, Salahshoor M, Naghsh E, Esfandiari E. Induction of chondrogenic differentiation of human adipose-derived stem cells by low frequency electric field. Adv Biomed Res. 2016;5:97.

126. Esfandiari E, Roshankhah S, Mardani M, Hashemibeni B, Naghsh E, Kazemi M, et al. The effect of high frequency electric field on enhancement of chondrogenesis in human adipose-derived stem cells. Iran J Basic Med Sci. 2014;17(8):571-6.

127. Matos MA, Cicerone MT. Alternating current electric field effects on neural stem cell viability and differentiation. Biotechnol Prog. 2010:26(3):664-70.

128. Morimoto T, Yasuhara T, Kameda M, Baba T, Kuramoto S, Kondo A, et al. Striatal stimulation nurtures endogenous neurogenesis and angiogenesis in chronic-phase ischemic stroke rats. Cell Transplant. 2011;20(7):1049-64.

129. Feng JF, Liu J, Zhang L, Jiang JY, Russell M, Lyeth BG, et al. Electrical guidance of human stem cells in the rat brain. Stem Cell Reports. 2017;9(1):177-89.

130. Li S, Lu D, Tang J, Min J, Hu M, Li Y, et al. Electrical stimulation activates fibroblasts through the elevation of intracellular free $\mathrm{Ca}(2+)$ : potential mechanism of pelvic electrical stimulation therapy. Biomed Res Int. 2019; 2019:7387803.

131. Deng Y, Dong Y, Liu Y, Zhang Q, Guan X, Chen X, et al. A systematic review of clinical studies on electrical stimulation therapy for patients with neurogenic bowel dysfunction after spinal cord injury. Medicine (Baltimore). 2018:97(41):e12778.

132. Zheng X, Chen D, Yan T, Jin D, Zhuang Z, Tan Z, et al. A randomized clinical trial of a functional electrical stimulation mimic to gait promotes motor recovery and brain remodeling in acute stroke. Behav Neurol. 2018;2018:8923520.

133. Miura G, Sugawara T, Kawasaki Y, Tatsumi T, Nizawa T, Baba T, et al. Clinical trial to evaluate safety and efficacy of transdermal electrical stimulation on visual functions of patients with retinitis pigmentosa. Sci Rep. 2019;9(1):11668.

\section{Publisher's Note}

Springer Nature remains neutral with regard to jurisdictional claims in published maps and institutional affiliations.

Ready to submit your research? Choose BMC and benefit from:

- fast, convenient online submission

- thorough peer review by experienced researchers in your field

- rapid publication on acceptance

- support for research data, including large and complex data types

- gold Open Access which fosters wider collaboration and increased citations

- maximum visibility for your research: over $100 \mathrm{M}$ website views per year

At $\mathrm{BMC}$, research is always in progress.

Learn more biomedcentral.com/submissions 